\section{Boban Stojanović1}

University of Niš, Faculty of Economics

Milan Kostić

University of Kragujevac, Faculty of Economics
ORIGINAL SCIENTIFIC ARTICLE doi:10.5937/ekonomika1801001S

Received December, 05, 2017

Accepted: February, 12, 2018

\title{
INFORMATION AND COMMUNICATION TECHNOLOGIES PRODUCT MARKET AND PROTECTION OF COMPETITION IN THE REPUBLIC OF SERBIA
}

\begin{abstract}
Starting from the fact that the importance of information and communication technologies (ICT) for the development of a national economy is high, it has been examined how this sector and the situation in individual markets in the sector affect competition policy. All the most important markets of the ICT sector of Serbia are characterized by a high level of concentration measured using the HerfindahlHirschman Index (HHI) with a tendency of decrease. In such circumstances, there are three directions of changing approach to competition policy: (1) changing the angle of observation and estimation of the relevant market boundaries; (2) balancing between good and bad parties related to joining in research and development (R\&D), and (3) a more attentive attitude towards patents and licenses, as a basis for the protection of intellectual property, but also barriers to entry into new market. What is required of contemporary competition policy is a dichotomous view of the boundaries of relevant product market. One which is focused on the services of one market from the ICT sector and the second one focused on integral observation of linked services from the ICT sector. Moreover, national competition bodies are required to mutually cooperate at a higher level through the formalization of the information exchange protocol. In the segment related to cooperation in the field of research and development and affirmation of intellectual property protection, through patents and licenses, special attention is required from competition policy so as not to impair the welfare of these institutions, while at the same time preventing uncompetitive behavior.
\end{abstract}

Keywords: information and communication technology (ICT), concentration, competition policy, cooperation between national competition authorities.

JEL Classification: D43, L41, L82, L86

\footnotetext{
${ }^{1}$ dr.boban.stojanovic@gmail.com

${ }^{2}$ mkostic@kg.ac.rs
} 


\title{
ТРЖИШТЕ ПРОИЗВОДА ИНФОРМАЦИОНО- КОМУНИКАЦИОНИХ ТЕХНОЛОГИЈА И ЗАШТИТА КОНКУРЕНЦИЈЕ У РЕПУБЛИЦИ СРБИЈИ
}

\begin{abstract}
Апстракт
Полазећи од тога да је значај информационо-комуникационих технологија (ИКТ) за развој једне националне економије веома велики у раду је испитивано како овај сектор и стање на појединачним тржиштима из овог сектора утичу на политику заштите конкуренције. Сва најзначајнија тржишта ИКТ сектора Србије карактерише висок ниво концентрације мерене Херфиндал-Хиршмановим индексом (ХХИ) са тенденцијом смањења. У таквим околностима три су правца промене приступа политици заштите конкуренције и то: (1) промена угла посматрања и процене граница релевантног тржишта; (2) балансирање између добрих и лоших страна везаних за повезивање у сфери истраживања и развоја (И\&Р) и (3) обазривији однос према патентима и лиценцама, као основама заштите интелектуалне својине, али и баријерама уласка на ново тржиште. Оно што се од савремене политике заштите конкуренције захтева је дихотоми поглед на границе релевантног тржишта производа. Један усмерен на услуге једног тржиште из ИКТ сектора и други усмерен на интегрално посматрање везаних услуга из ИКТ сектора. Такође, од националних тела за заштиту конкуренције се захтева и виши ниво међусобне сарадње кроз формализовање протокола о размени информација. У сегменту који се тиче сарадње у сфери истраживања и развоја и афирмације заштите интелектуалне својине, кроз патенте и лиценце захтева се посебна обазривост политике заштите конкуренције, како се не би нарушила добробит поменутих института, а истовремено спречило неконкурентно понашање.
\end{abstract}

Кључне речи: информационо-комуникациона технологија (ИКТ), концентрација, политика заштите конкуренције, сарадња између националних ауторитета за заштиту конкуренције.

\section{Introduction}

The importance of information and communication technologies (ICT) and their products, or services, for the accelerated development of a national economy is high. However, like other economic sectors, this one is also not immune to various market anomalies. Most often it is the need of big participants to impair free competition and achieve better financial result. A good example is the media content distributor, Serbia Broadband - Serbian Cable Network Ltd. Belgrade (SBB), where the Commission for the Protection of Competition of the Republic of Serbia identified abuse of a dominant position through: (1) leading inappropriate promotional campaigns on the territories of certain municipalities of Belgrade, (2) the conclusion of exclusive contracts for the distribution of foreign channels with foreign production companies, (3) charging unreasonably high monthly fees for the maintenance of the cable network, (4) determining unreasonably high tariffs for broadcasting programs of certain local TV stations, etc. (Kostić, 2010, pp. 145-146). This and similar cases require proactive competition policy. 
It implies certain changes, especially in the segment related to cooperation between national competition bodies, since certain economic entities from this activity are parts of some larger transnational companies (TNC), which carry out similar offences in other countries in which they operate.

The subject of the paper is the analysis of the most important markets of information and communication technologies (ICT) of Serbia and the possible responses of competition policy to various attempts to limit free competition in this area. Starting from this defined subject of the research, the paper is structured so that, in addition to the introduction and concluding remarks, it contains three independent and interconnected parts. The first part of the paper presents literature review, which deals with the measurement of market limitation, as well as methodology used in the research. In the second part of the paper, an analysis of the situation in individual ICT markets was carried out, while the third part deals with recommendations on the direction in which competition policy of the Republic of Serbia should be developed, in order to provide an adequate response to events in the ICT sector.

\section{Literature review and methodology}

A large number of authors analyzed the conditions of competition in certain activities. Among the important works one can distinguish the work of Vanlonmmel, de Brabander, and Liebaraers (1977), which studies the degree of concentration through the example of 119 sectors of Belgian industry. Also, there is the work of Belobaba and Van Acker (1994), who analyzed the level of concentration in the US airline market, as well as the work of Einarsson (2008) who explored the level of concentration in the retail markets of the Nordic countries. In Serbia, we can highlight the works of Stojanović and Radivojević (2010), which deals with the concentration of non-specialized retail trade of Niš, and the work of Kostić, Maksimović, and Stojanović (2016) which analyzes the trends in the level of concentration in the insurance market of Slovenia, Croatia, and Serbia. Concerning the works related to the ICT sector of Serbia, we highlight two very up to date works. The first one by Maksimović, Radosavljević, and Borisavljević (2011) is related to determining concentration in the market of media distribution. The authors concluded that media distribution market of Serbia is extremely concentrated with the values of the Herfindahl-Hirschman Index (HHI) of 3344 index points for 2008 and 3169 index points for 2009 (Maksimović, Radosavljević \& Borisavljević, 2011, p. 37). The second one is related to the level of limitation of the mobile telephony market of Serbia by Kostić, Stojanović, Radukić (2016). In this paper, the authors have shown that the mobile telephony market of Serbia is extremely concentrated, but that there is a trend of decrease in the level of concentration measured using the Herfindahl-Hirschman index (HHI) (Kostić, Stojanović \& Radukić, 2016, p. 333). Starting from the above mentioned articles, the research that has been conducted is a qualitative step forward since it provides an integral image of competition conditions in the ICT sector by analyzing all of the most important markets in the sector.

Analysis of the conditions of competition in the ICT sector was conducted using the data of the Regulatory Agency for Electronic Communications and Postal Services of the Republic of Serbia (RATEL). The research was carried out for the period 
between 2007 and 2016. In order to determine the limitation, i.e. market concentration, Herfindahl-Hirschman Index (HHI) was used, which is calculated based on the market shares obtained through participants' revenues derived from the analyzed activity. HHI is generally accepted and certainly the only complete indicator of market concentration. It is calculated according to the form (Stojanović \& Kostić, 2013, p. 334):

$$
H H I=\sum_{i=1}^{n}\left(s_{i}^{2}\right)
$$

where $s_{i}$ is the market share of the $i$-th company.

Herfindahl-Hirschman Index (HHI), theoretically, can have a value between 0 and 10000. In the case of an atomized supply, when each participant's supply tends to 0 the index value also tends to 0 . In case of monopoly value of the index is 10000 . HHI reference values are given in Table 1.

Table 1. HH Index Reference Values

\begin{tabular}{|c|c|}
\hline alue of $\mathbf{H H}$ index & Levels of concentration of supply \\
\hline $\mathrm{HHI}<1500$ & Unconcentrated market \\
\hline $1500 \leq \mathrm{HHI} \leq 2500$ & Moderately concentrated market \\
\hline $\mathrm{HHI}>2500$ & Highly concentrated market \\
\hline \multicolumn{2}{|c|}{ Source: Horizontal Merger Guidelines, 2010, p. 18}
\end{tabular}

For markets where data on the amount of revenue, and therefore the size of market share, were not available only the number of registered participants (operators, distributors, or providers) was specified. It is believed that this indicator can also depict picturesque situation in a market. Data analysis was performed in the MiniTab 15 statistical program.

\section{Analysis of the situation in the information and communication technologies (ICT) markets of Serbia}

In contemporary business conditions, the importance of the ICT sector is very high. This may not be perceived by the contribution it has to gross domestic product (GDP), however, as new technologies develop, the significance of this sector will grow. Table 2 lists the share of the ICT sector in the total GDP of the selected countries.

Table 2. The share of the ICT sector in GDP of the selected countries in percentages

\begin{tabular}{|l|r|r|r|r|r|r|r|r|}
\hline & \multicolumn{1}{|c|}{2007} & \multicolumn{1}{c|}{2008} & \multicolumn{1}{c}{2009} & \multicolumn{1}{c}{2010} & \multicolumn{1}{c|}{2011} & \multicolumn{1}{c}{2012} & 2013 & \multicolumn{1}{c|}{2014} \\
\hline Sweden & $\mathbf{6 . 5 4}$ & - & $\mathbf{6 . 2 7}$ & $\mathbf{6 . 4 0}$ & - & - & - & $\mathbf{6 . 4 1}$ \\
\hline Hungary & 5.84 & $\mathbf{5 . 8 3}$ & 5.75 & 5.71 & $\mathbf{5 . 9 9}$ & $\mathbf{5 . 8 2}$ & $\mathbf{5 . 8 7}$ & 5.69 \\
\hline Bulgaria & 5.98 & 5.02 & 4.86 & 4.83 & 4.64 & 4.58 & 4.69 & 4.90 \\
\hline Germany & 4.72 & 3.96 & 4.12 & 3.88 & 4.02 & 3.98 & 4.05 & 4.18 \\
\hline Estonia & 4.57 & 4.40 & 4.98 & 4.79 & 5.04 & 4.69 & 4.61 & 4.91 \\
\hline
\end{tabular}




\begin{tabular}{|l|r|r|r|r|r|r|r|r|}
\hline Slovenia & 4.08 & 3.34 & & 3.51 & 3.49 & 3.57 & 3.62 & 3.62 \\
\hline Romania & - & 3.27 & $\mathbf{3 . 2 7}$ & 3.09 & 3.07 & 3.17 & 3.12 & 3.31 \\
\hline Greece & $\mathbf{2 . 7 1}$ & $\mathbf{2 . 6 1}$ & - & $\mathbf{2 . 1 3}$ & $\mathbf{2 . 0 6}$ & $\mathbf{2 . 0 4}$ & $\mathbf{1 . 9 8}$ & $\mathbf{1 . 8 4}$ \\
\hline
\end{tabular}

Source:http://ec.europa.eu/eurostat/tgm/table.do?tab=table\&plugin=1\&language $=$ en \&pcode $=$ tin00074 downloaded on November 08th, 2017

As Table 2 shows, the share of the ICT sector in GDP of the selected countries ranges from $1.84 \%$ in Greece to $6.54 \%$ in Sweden. Serbia's experience related to ICT share in GDP does not differ from the experience of these countries. In Serbia, the share of revenue from this sector in GDP in the period between 2006 and 2016 ranged between $4.70 \%$ and $5.66 \%$. It was the highest in 2011, and at lowest in 2007. Table 3 shows the share of the revenue of the ICT sector in total GDP of Serbia.

Table 3. Share of ICT revenues in the total GDP of Serbia in percentages

\begin{tabular}{|l|r|r|r|r|r|r|r|r|r|r|r|}
\hline Year & 2006 & 2007 & 2008 & 2009 & 2010 & 2011 & 2012 & 2013 & 2014 & 2015 & 2016 \\
\hline Share & 5.60 & 4.70 & 4.87 & 4.76 & 5.29 & 5.66 & 5.52 & 4.85 & 4.50 & 4.72 & 4.51 \\
\hline
\end{tabular}

Source: RATEL http://www.ratel.rs/market/overviews_of_telecom_market.129.html, downloaded on November 07th, 2017

It is very important to consider the contribution of each individual category of ICT services to the total revenue of the ICT sector, since the contribution of all segments is not identical. The largest contribution to the total revenue of the ICT sector in Serbia is mobile telephony, followed by fixed telephony, fixed broadband Internet, and distribution of media content. These four categories make up $98.4 \%$ of total ICT revenue (Table 4).

Table 4 Structure of revenues of the ICT sector by services for 2016

\begin{tabular}{|l|r|}
\hline \multicolumn{1}{|c|}{ Category of ICT Service } & Percentage in 2016 \\
\hline Mobile network & $59 \%$ \\
\hline Fixed network & $17.9 \%$ \\
\hline Fixed broadband Internet access & $11.8 \%$ \\
\hline Distribution of media content & $9.7 \%$ \\
\hline VAS & $0.5 \%$ \\
\hline VoIP & $0.4 \%$ \\
\hline Leased lines & $0.4 \%$ \\
\hline Radio diffusion & $0.3 \%$ \\
\hline Total & $100 \%$ \\
\hline
\end{tabular}

Source: RATEL http://www.ratel.rs/market/overviews_of telecom_market.129.html, downloaded on November 07th, 2017

In accordance with previously displayed classification of individual categories of revenue and their contribution to the total ICT sector revenue, the analysis of the conditions of competition was conducted in four most important markets of the sector. Wherever possible, HHI was calculated as the most significant indicator of concentration, and where this was not possible only the number of participants was specified (Table 5). 
Table 5. Analysis of the level of concentration in the selected markets of the ICT sector of Serbia

\begin{tabular}{|r|r|r|r|r|}
\hline Year & $\begin{array}{c}\text { HHI } \\
\text { mobile } \\
\text { telephony }\end{array}$ & $\begin{array}{c}\text { Number of } \\
\text { operators } \\
\text { fixed telephony }\end{array}$ & $\begin{array}{c}\text { Number of } \\
\text { providers (HHI) } \\
\text { Internet services }\end{array}$ & $\begin{array}{c}\text { Number of } \\
\text { operators } \\
\text { (HHI) distribution } \\
\text { of media content }\end{array}$ \\
\hline 2007 & 4914 & 1 & 159 & $79(3236)$ \\
\hline 2008 & 4506 & 1 & 197 & $79(3177)$ \\
\hline 2009 & 4288 & 1 & 199 & $78(2932)$ \\
\hline 2010 & 3901 & 4 & 192 & $80(3170)$ \\
\hline 2011 & 3717 & 4 & 232 & $82(3128)$ \\
\hline 2012 & 3630 & 6 & 222 & $94(3495)$ \\
\hline 2013 & 3534 & 10 & 221 & $94(3124)$ \\
\hline 2014 & 3503 & 14 & 217 & $98(3104)$ \\
\hline 2015 & 3506 & 17 & $212(2904)$ & $90(2905)$ \\
\hline 2016 & 3486 & 30 & $214(2799)$ & $90(2993)$ \\
\hline
\end{tabular}

\section{Source: Authors'calculation}

It can be concluded that the most limited market is fixed telephony market, where the number of registered operators until 2010 was one, when other operators started receiving license. The operator who was the only one licensed by 2010 and up to now is the most important participant in the market is Telekom Serbia. The next one according to the level of limitation is the mobile telephony market with three registered operators and HHI values above 3000 index points. What should be said is that the value of the HHI index for this market has a downward trend but is still expected to be above 3000 index points. Forecasted HHI value for 2017 is 3645 index points (Figure 2).

\section{Figure 2. Trend analysis of the HHI movement in the mobile telephony market of Serbia}

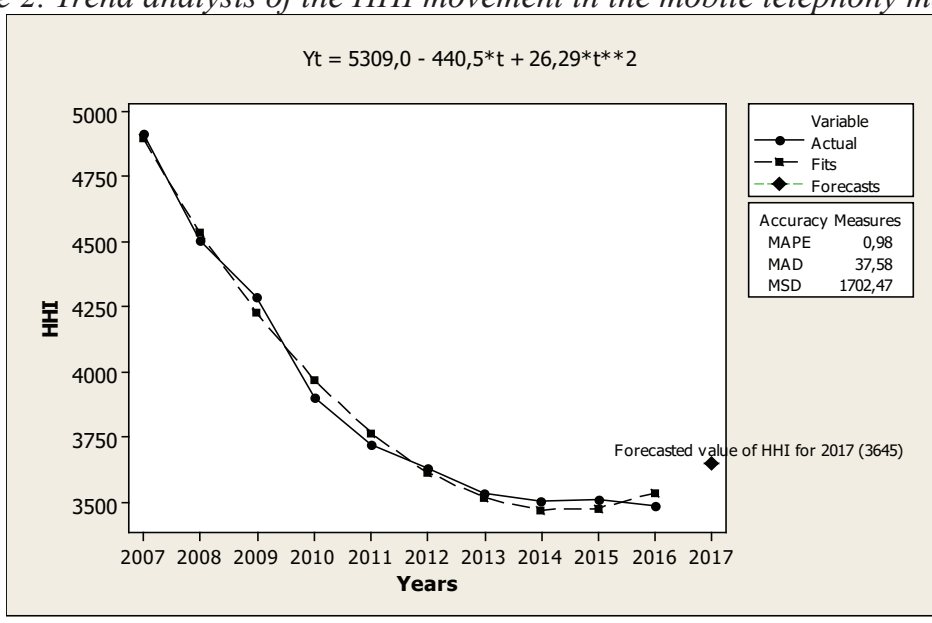

Source: Authors'calculation 
Regardless of the fact that the limitation of this market decreases, HHI value can never be lower than 3333 index points, since the number of participants in this market is always the same i.e. three. Even for the forecasted value of 3645, it can be said that it is close to the lower threshold and as such indicates a relatively uniform distribution of market power between the three existing market participants. Only with the introduction of a new operator the HHI value could drop further, even below 3000 index points. After this market, according to the level of limitation, the market of media distribution is the following, where the value of $\mathrm{HHI}$ is about 3000 points with the trend of further decline, regardless of occasional fluctuations of HHI values including both rise and fall (Figure 3).

Figure 3. Trend analysis of the movement of HHI in the market of distribution of media content in Serbia

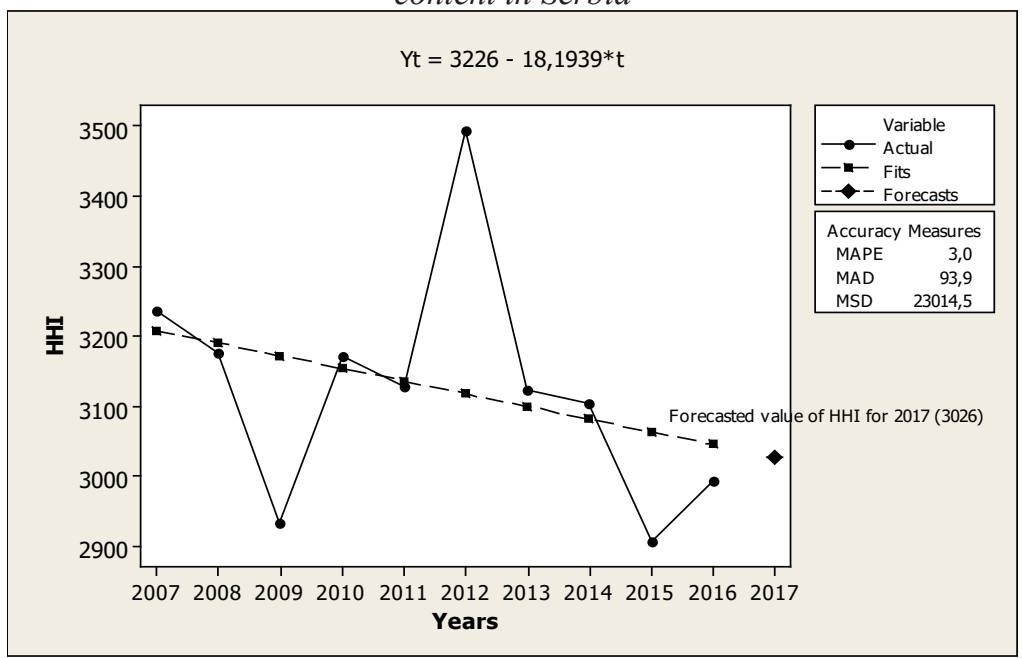

Source: Authors'calculation

Forecasted HHI value for this market in 2017 was 3026 index points. It is important to note that the number of operators in the market varies from 78 in 2008 to 98 in 2014. The most important operator in the market is SBB, with a market share of over $50 \%$ by 2014 and slightly below 50\% in 2015 and 2016 (47 and 48\% respectively).

The last one according to the level of limitation is the market of broadband Internet access, where the number of participants (providers) in the last six years was constantly above 200 participants and where the value of $\mathrm{HHI}$, for the years for which data were available, is lower compared to the previous two markets. Insufficient data did not allow the definition of the trend of HHI movement and forecast of its value for 2017. This market is dominated by SBB and Telekom Serbia. In 2015, SBB had 47\% of the market share, while Telekom Serbia had $45.9 \%$ of market share in 2016.

Examples of SBB and Telekom Serbia, as well as other participants in the ICT markets, such as Kopernikus Technology, Radius Vektor, Ikom etc., are showing us that these markets are becoming more and more complex in terms of the type of services they provide. Namely, as a rule, companies from the ICT sector provide a number of linked services, therefore the new way of definition relevant market become main question in 
competition policy for ICT sector. The best example is the fact that the market of the distribution of media content, that is cable operators, is supported by Internet and fixed telephony distribution services. This will greatly complicate the analysis of these markets in the future. Furthermore, there is the ownership connection of the entities operating in these markets, which can change the conclusions about the level of market limitations of individual services from the ICT sector. The question arises: what can competition policy in Serbia do under such circumstances?

\section{The role and challenges of competition policy in the ICT sector}

In the era of the expansion of the ICT sector, a global view of competition policy is changing. The situation is also similar in Serbia. Under the influence of high concentration and interweaving services from individual markets, there are three basic directions in which competition policy, related to contemporary information and communication technology (ICT) is changing. The directions of change are:

1. Changing the angle of observation and assessment of the relevant market;

2. Balancing between good and bad parties related to joining in the sphere of research and development $(\mathrm{R} \& \mathrm{D})$ and,

3. Attentive attitude towards patents and licenses, as the basis for the protection of intellectual property, as well as the barriers to entering the new market.

When it comes to the relevant market, it can be said that this is the most important element and the starting point for acting in competition protection segment. Proper assessment of the market share and the indirect market power of economic entities depend on the correct definition of the relevant market. If the boundaries of the market are set too wide, consequently, it could appear that companies have significantly lower market power, contrary to the fact that if narrower boundaries are set, it could appear that companies have higher market power, and in reality this is not the case. The relevant market has two components, one related to products and another related to the territory where these products are offered, therefore there is a relevant product market and a relevant geographic market. Competition protection theory and the legislation of most developed countries understand the relevant product market and the relevant geographic market in an identical way. Thus, the relevant product market is a set of goods or services that consumers and other users consider substitutable in terms of usual purposes, characteristics, and prices, while the relevant geographic market is the territory in which participants participate in supply or demand and where the same or similar conditions of competition exist, which are significantly different from the conditions of competition in neighboring territories (European Commission, 1997, Commission Notice on the Definition of the Relevant Market for the Purposes of Community Competition Law ${ }^{\text {paras }}{ }^{7}$ and 8 ). As such, the phenomenon of the relevant market is narrower than the general concept of the market, which includes the exchange of goods and services in all territories, regardless of the conditions of competition and the existence of substitutability of products (Labus, 2008, p. 50).

Based on the research conducted on the case of individual ICT markets, it can be said that reviewing the approach to setting relevant market boundaries should go in two 
directions. The first one is related to the production component and concerns the fact that the market of a certain category of products (services) is no longer individual as a separate entity, but that the services from the supply of individual participants intertwine with each other. In other words, consumers are required to make linked purchases in the sense that the purchase of one product entails the purchase of another product or service. Even when this is not conditioned, consumers themselves often opt for linked purchases for the purpose of reducing transaction costs. In such circumstances, the relevant product market should be observed at two levels, the first with regard to specific services or products, and the second with regard to a number of related services or products.

The second direction of changing the approach to defining the relevant market boundaries is related to geographic component, where the national competition bodies are required to mutually cooperate at a higher level. Cooperation should be more important since the market in which companies from the sector operate is of global character, in a geographical sense. A good basis for better communication and exchange of information is the existence of the International Competition Network (INC), in which procedures for the exchange of information concerning global market participants should be formalized. Moreover, as regards the Commission for the Protection of Competition of the Republic of Serbia, it should be noted that regional cooperation networks should play a significant role in the exchange of information, in particular Regional Center for Competition (RCC), based in Budapest, founded by the OECD and the Hungarian Competition Authority, as well as Sofia Competition Forum (SCF), established by UNCTAD and Bulgarian Competition Authority. However, as in the case of INC, cooperation comes down to informal communication, and less to formal exchange of information. There is space for action in a part that concerns formalization of cooperation. Model for this could be the European Competition Network (ECN) through which the cooperation between individual members of the network is precisely defined, and these are the national competition bodies of the EU Member States.

When analyzing the conditions of competition, special attention should be paid to the research and development cooperation between the companies in the ICT sector. Research and development (R\&D) are very important elements for the survival and development of companies in the ICT sector, because the world economy is characterized by a new technological revolution (4.0 industry), which includes new knowledge, capabilities, new production structures, a new way of joining companies in the sphere of research work, etc. (Maksimović \& Kostić, 2012, p. 51). In such business conditions, price competition is often replaced by innovation competition. Even in 1942, Schumpeter argued that price, as a privileged variable in large companies' strategic thinking, lost its dominance and now the competition that implies new products and the application of new technologies, through which the survival and development of companies are ensured, takes over the primacy (Schumpeter, 1960, p. 130). This is especially emphasized in the companies of the ICT sector. Companies in this sector make decision to cooperate with other companies to reduce the risk and financial pressure of large research and development investments. Co-ordination of innovative activities is achieved through joint investments and the establishment of joint research centers or through various forms of technical cooperation. Such moves reduce the risk of eventual competitive outpacing, and also reduce technology improvement cost. Companies which do not join together can lead themselves to disadvantage, as their profits will be lower than profits earned 
by companies joined with innovative activities. The losses from missed opportunities, which in such conditions grow, are not negligible. Such forms of horizontal joining are subject to criticism, as they lead to market cartelization. However, if they are entirely related to $R \& D$, the benefits they bring, through the reduction of the risk of new products and technology introduction, are greater than the damage caused by market limitation. It follows that such a joining contributes to economic and social progress (Bomol, 2002, pp. 104-105). It can be said that cooperation in this field is acceptable to the extent that the benefits of new investments do not become lower than the social costs incurred due to limitation of competition.

According to the Competition Law of the Republic of Serbia, research and development agreements may be exempted from the prohibition if they contribute to the improvement of production and trade, or incite technical or economic progress, while providing consumers with a fair share of benefits, provided that they do not exclude competition in the relevant market or in its substantial part. (Official Gazette of the Republic of Serbia 51/09, Law on Protection of Competition Article 11). Exemption cannot be longer than eight years (Official Gazette of the Republic of Serbia 51/09, Law on Protection of Competition Article 12). The Regulation of the Government of the Republic of Serbia defines more closely the agreements from the sphere of research and development that are exempted from prohibition; the conditions to be fulfilled by these agreements; elements that agreements which are subject to an exemption must not contain; as well as the precise terms of the validity of the exemption (Official Gazette of the Republic of Serbia 11/10, Regulation on research and development agreements between undertakings operating on the same level of production or distribution chain exempted from prohibition).

One of the major barriers that a new company can encounter is patents and licenses owned by an innovator company, which already operates in a particular market. Patents represent a conceived legal creation aimed at protecting the right to produce and provide certain services. The ownership of the patent provides the company with the possibility of acquiring large profit in a limited period. The intention is to encourage creativity and investment in the development of products and processes by protecting the innovator and his right to exploit the product. Disadvantage of such protection is in the fact that patents limit competition to a great extent through the difficult movement of innovation, and therefore knowledge, between companies. As in the case of cooperation in research and development, here is also required an adequate response from the competition policy, which would not jeopardize the protection of innovation, and at the same time would not prevent the entry of new competitors.

\section{Concluding remarks}

The conditions of competition in the ICT sector of Serbia are characterized by a high level of concentration with the trend of its decline. However, regardless of this trend, the future level of concentration in this sector is expected to be high. What is also expected is the interweaving of services offered by companies from the ICT sector. These tendencies pose a challenge to competition policy. Some of the challenges are listed in the paper. The response of the competition policy should be proactive, aimed at changing 
the view of defining relevant market and increasing the level of cooperation with other national competition bodies. Market for this category of products is global rather than local, so the national competition bodies are required to mutually cooperate at a higher level in order to prevent potential competition distortions by market participants. As far as cooperation in $R \& D$ is concerned, caution is needed, since this segment of activity coordination can contribute to faster technical and economic progress, however, it loses the point if there is no fair benefit from it to customers and if it excludes healthy competition in the market. Contemporary competition policy is here to ensure fairness and competition in the market.

\section{Reference}

Belobaba, P., \& Van Acker, J. (1994). Airline Market Concentration - An Analyses of US origin-destination markets. Journal of Air Transport Management, 1 (1), 5-14.

Bomol, J. W. (2002). The Free-Market Innovation Machine - analyzing the growth miracle of capitalism, USA. Princeton, USA: Princeton University Press.

Einarsson, A. (2008). The Retail Sector in the Nordic Countries: A Description of the Differences, Similarities, and Uniqueness in the Global Market. Journal of Retailing and Consumer Services, 15 (6), 443-451.

European Commission. (1997, 12 9). Commission Notice on the Definition of the Relevant Market for the Purposes of Community Competition Law. Official Journal of European Union, OJ C 372, paras 7 and 8.

Eurostat. (n.d.). Percentage of the ICT sector on GDP. Retrieved 11 8, 2017 from Eurostat: http://ec.europa.eu/eurostat/tgm/table.do?tab=table\&plugin=1\&langua ge $=$ en\&pcode $=$ tin00074

Kostić, M. (2010). Protection of competition in Serbia - institutional foundations, problems and possible directions of improvement. Institutional changes as determinants of the economic development of Serbia (pp. 136-150). Kragujevac: Faculty of Economics University of Kragujevac.

Kostić, M., Maksimović, L., \& Stojanović, B. (2016). The limitations of competition in the insurance markets of Slovenia, Croatia and Serbia. Economic Research, 29 (1), 395-418.

Kostić, Z., Stojanović, B., \& Radukić, S. (2016). Measuring the level of competition in the Serbian mobile telecommunications market. Economic Themes, 54 (3), 323-343.

Labus, M. (2008). Comparative analysis of relevant market - concept and application. Company economics, 56 (1-2), 48-60.

Maksimović, L., \& Kostić, M. (2012). Models of price competition in oligopolistic market and their applicability. Economic horizons, 12 (2), 39-56.

Maksimović, L., Radosavljević, G., \& Borisavljević, K. (2011). Concentration in the radio television program distribution market in the Republic of Serbia. Industry, 39 (3), 31-43. 
RATEL. (n.d.). Overviews of telecom market. Retrieved 11 7, 2017 from RATEL: http://www.ratel.rs/market/overviews_of_telecom_market.129.html

Official Gazette of the Republic of Serbia 11/10. Regulation on research and development agreements between undertakings operating on the same level of production or distribution chain exempted from prohibition. Belgrade: Republic of Serbia

Official Gazette of the Republic of Serbia 51/09, Law on Protection of Competition Belgrade: Republic of Serbia

Stojanović, B., \& Kostić, M. (2013). Competition policy and the impact of market structure on companies' profitability. Company economics (56), 325-338.

Stojanović, B., \& Radivojević, V. (2010). Concentration of supply: A form of market imperfection: Example of non-specialized retail trade in Niš. Company Economics, 58 (7-8), 327-338.

Schumpeter, J. (1960). Capitalism, socialism, and democracy. Belgrade: Culture.

U.S. Department of Justice and Federal Trade Commission. (2010). Horizontal Merger Guidelines. Washington.

Vanlommel, E., de Brabander, B., \& Liebaers, D. (1977). Industrial Concentration in Belgium: Empirical Comparison of Alternative Seller Concentration Measures. The Journal of Industrial Economics, 26 (1), 1-20. 